\title{
Enhanced Efficiency Foliar Nitrogen and Pyraclostrobin Applications for High Yielding Corn
}

\author{
Kelly A. Nelson ${ }^{1}$, Christopher J. Dudenhoeffer ${ }^{2}$, Bruce Burdick $^{3} \&$ Dana Harder $^{2}$ \\ ${ }^{1}$ Division of Plant Sciences, University of Missouri, Novelty, MO, USA \\ ${ }^{2}$ Lee Greenley Jr. Memorial Research Center, University of Missouri, Novelty, MO, USA \\ ${ }^{3}$ Hundley-Whaley Center, University of Missouri, Albany, MO, USA \\ Correspondence: Kelly A. Nelson, University of Missouri, Lee Greenley Jr. Memorial Research Center, Novelty, \\ MO 63460, USA. Tel: 1-660-739-4410. E-mail: nelsonke@missouri.edu
}

Received: June 23, 2015 Accepted: July 23, 2015 Online Published: September 15, 2015

doi:10.5539/jas.v7n10p17 URL: http://dx.doi.org/10.5539/jas.v7n10p17

\begin{abstract}
Combining a foliar fertilizer and fungicide in a single application could complement soil-applied nitrogen $(\mathrm{N})$ and reduce application costs. Limited research has evaluated such combinations for high-yield corn (Zea mays L.) production systems. This research evaluated the effect of mixing order of enhanced-efficiency foliar N (30-0$0-0$, Nitamin) rates $\left(0,9\right.$, and $\left.28 \mathrm{~L} \mathrm{ha}^{-1}\right)$ with pyraclostrobin under different crop-yield environments (soil applied $\mathrm{N}$ at 84,169 , and $337 \mathrm{~kg} \mathrm{ha}^{-1}$ ) on crop injury, disease severity, chlorophyll content, grain quality, and yield at Novelty and Albany, Missouri, in 2010 and 2011. There was no effect of 30-0-0-0 at 9 or $28 \mathrm{~L} \mathrm{ha}^{-1}$ on corn yields in low- (soil applied $\mathrm{N}$ at $84 \mathrm{~kg} \mathrm{ha}^{-1}$ ) or medium-yield environments (soil applied $\mathrm{N}$ at $169 \mathrm{~kg} \mathrm{ha}^{-1}$ ). In a highyield environment (soil applied $\mathrm{N}$ at $337 \mathrm{~kg} \mathrm{ha}^{-1}$ at Novelty and Albany), 30-0-0-0 at $9 \mathrm{~L} \mathrm{ha}^{-1}$ increased grain yields $0.38 \mathrm{Mg} \mathrm{ha}^{-1}$ (3.7\%) compared to the non-treated control, but 30-0-0-0 at $28 \mathrm{~L} \mathrm{ha}^{-1}$ did not increase yield due to $3-4 \%$ crop injury. In a high-yield environment $\left(>9.4 \mathrm{Mg} \mathrm{ha}^{-1}\right)$, pyraclostrobin increased yields 3.9 to $7.1 \%$ ( 0.38 to $\left.0.7 \mathrm{Mg} \mathrm{ha}^{-1}\right)$ compared to the non-treated plants. This study found no significant effect of mixing order on corn yield response when 30-0-0-0 was applied with pyraclostrobin at $0.055 \mathrm{~kg}$ ai ha ${ }^{-1}$. The severity of diseases (Cercospora zea-maydis, Puccinia sorghi, and Exserohilum turcicum), which was less than 12\% depending on the treatment, was affected by soil-applied $\mathrm{N}$ rate, 30-0-0-0 rate, and pyraclostrobin, depending on the site-year. Pyraclostrobin at $0.11 \mathrm{~kg}$ ai ha ${ }^{-1}(7.1 \%)$ and 30-0-0-0 at $9 \mathrm{~L} \mathrm{ha}^{-1}(3.7 \%)$ were the highest-yielding treatments compared to the non-treated control with good crop safety.
\end{abstract}

Keywords: corn, disease, fungicide, nitrogen, pyraclostrobin, strobilurin

\section{Introduction}

During the past five years in the U.S., farmers grew corn on an estimated average area of 34 million hectares, yielding $9.4 \mathrm{Mg} \mathrm{ha}^{-1}$ at an annual value of $\$ 65$ billion (USDA-NASS, 2015). High-yield corn production systems have applied fungicide (Wegulo et al., 1997; Bradley \& Ames, 2010; Nelson \& Meinhardt, 2011) to maximize plants' photosynthetic efficiency and meet a growing demand for food, fuel, and fiber. Several field experiments have evaluated how fungicide applications affect hybrid corn (Bowen \& Pedersen, 1988; Bair et al., 1990; Ward et al., 1997; Munkvold et al., 2001; Bradley \& Ames, 2010; Nelson \& Meinhardt, 2011), hybrid seed corn (Wegulo et al., 1997), and sweet corn (Pataky \& Eastburn, 1993; Shah \& Dillard, 2010) to manage diseases such as gray leaf spot (Cercospora zea-maydis), common rust (Puccinia sorghi), and northern leaf blight (Exserohilum turcicum). These foliar diseases have reduced corn yields up to 70\% (Rodriguez-Ardon et al., 1980; Perkins \& Pedersen, 1987; Bair et al., 1990; Ward et al., 1999). Strobilurin fungicides stimulate plant growth by reducing disease severity and by increasing nitrate uptake and assimilation in small grains (Köhle et al., 2002). Pyraclostrobin helps stimulate nitric oxide, a key messenger in plants (Conrath et al., 2004). The increased nitrate uptake and assimilation that follows an application of a strobilurin fungicide could justify applying $\mathrm{N}$ fertilizer at the time. Identifying a fertilizer that synergistically increases yield with a fungicide treatment can help manage disease, reduce application costs, and provide additional fertilizer when crop demand is greatest (Fageria et al., 2009).

Nitrogen fertilizer loss can reduce grain yields in both poorly drained and well-drained soils due to gaseous $\mathrm{N}$ 
loss (Nash et al., 2012, 2015; Nelson et al., 2014) and leaching losses, respectively (Ferguson et al., 1991; Dinnes et al., 2002). As a result, applying additional $\mathrm{N}$ or rescue $\mathrm{N}$ can avoid a reduction in grain yields (Scharf et al., 2002; Sripada et al., 2005; Nelson et al., 2011). Although, applying N late has aided in recovering potential yield losses (Scharf et al., 2002, 2011), broadcast-applied foliar $\mathrm{N}$ at high rates reduced yield due to crop injury (Nelson et al., 2011). Several researchers have evaluated foliar feeding $\mathrm{N}$ at various stages of corn development (Foy et al., 1953; Harder et al., 1982; Tomar et al., 1988; Bair et al., 1990; Novoa \& Villagrán, 2002). Producers can complement soil-applied $\mathrm{N}$ with foliar $\mathrm{N}$ and reduce costs by mixing it with a fungicide and applying them simultaneously (Fageria et al., 2009). Foliar N applied during corn grain fill increased grain N 10\% and P 4.7\% (Harder et al., 1982). Timing of $\mathrm{N}$ application did not affect the severity of northern corn leaf blight, but $\mathrm{N}$ applications that supplied a majority of the $\mathrm{N}$ after V12 were not recommended due to the potential for yield loss (Bair et al., 1990). In other research, foliar-applied $\mathrm{N}$ at $20 \mathrm{~kg} \mathrm{~N}$ ha $^{-1}$ was no substitute for soil applied $\mathrm{N}$ (Tomar et al., 1988). A major advantage of a foliar application is its quicker remediation of nutrient deficiencies than a soil application, especially when applied with a crop-protection chemical.

Chlorophyll meters can help diagnose $\mathrm{N}$ deficiency and provide recommendations for $\mathrm{N}$ rates and yield responses (Scharf et al., 2006; Zhang et al., 2008; Ziadi et al., 2008). Relative chlorophyll meter readings best predicted yield response to $\mathrm{N}$ applications required a high $\mathrm{N}$ reference (Hawkins et al., 2007), but absolute chlorophyll meter values were good predictors of grain yield from V10-R1 (Scharf et al., 2006). Farmers planning to apply fungicide could use a chlorophyll meter to help determine whether to combine enhanced efficiency foliar N fertilizer with the fungicide. Several commercially available foliar fertilizers were evaluated for their effect corn grain yields when applied at VT in the presence or absence of pyraclostrobin (Shetley et al., 2015). A slowly available $\mathrm{N}$ solution source at $9 \mathrm{~L} \mathrm{ha}^{-1}$ containing methylene urea, triazone, and urea (30-0-0-0, Nitamin, Koch Fertilizer, LLC., Wichita, Kansas) increased yields $10 \%\left(1.1 \mathrm{Mg} \mathrm{ha}^{-1}\right)$ at four of the six site years (Shetley et al., 2015).

Limited research has evaluated foliar fertilizers with strobilurin fungicides (Nelson \& Meinhardt, 2011) and the use of a slow-release N source may be beneficial at VT (Ritchie et al., 1993). If research could determine the relationship between chlorophyll readings, $\mathrm{N}$ rates and grain yield response, the knowledge would inform decisions on the best concentration for a VT application timing. This research evaluated the effect of mixing order of enhanced-efficiency foliar N (30-0-0-0) rates with pyraclostrobin under different crop yield production potentials on crop injury, disease severity, chlorophyll content, grain quality, and yield.

\section{Methods}

Field experiments were conducted in 2010 and 2011 at the Lee Greenley Jr. Memorial Research Center near Novelty, Missouri $\left(40^{\circ} 11^{\prime} 35.4^{\prime \prime} \mathrm{N}, 92^{\circ} 11^{\prime} 26.2^{\prime \prime} \mathrm{W}\right)$ and Hundley-Whaley Center near Albany, Missouri $\left(40^{\circ} 14^{\prime} 14.8^{\prime \prime} \mathrm{N}, 94^{\circ} 20^{\prime} 49.1 " \mathrm{~W}\right)$. Corn followed soybean [Glycine max (L.) Merr.], and conventional tillage was used at both sites. Plot sizes were 3 by $15 \mathrm{~m}$ and arranged in a randomized complete block design with six replications at each site. The experiment was a three-factor factorial including soil-applied ammonium nitrate at three rates $\left(84,169\right.$, and $\left.337 \mathrm{~kg} \mathrm{~N} \mathrm{ha}^{-1}\right)$, three enhanced-efficiency foliar $\mathrm{N}$ rates $(30-0-0-0$, Nitamin, at 0 , 9, and $28 \mathrm{~L} \mathrm{ha}^{-1}$ ), and four pyraclostrobin treatments (non-treated control, pyraclostrobin at $0.055 \mathrm{~kg}$ ai ha ${ }^{-1}$ plus nonionic surfactant added first plus 30-0-0-0, 30-0-0-0 added first plus pyraclostrobin at $0.055 \mathrm{~kg}$ ai ha ${ }^{-1}$ plus nonionic surfactant, and pyraclostrobin at $0.11 \mathrm{~kg}$ ai ha ${ }^{-1}$ added first followed by nonionic surfactant and 30-0-0-0). The non-ionic surfactant was Activator- $90^{\circledR}$ (Loveland Industries Inc., Greeley, CO), a mixture of alkylpolyoxyethylene ethers and free fatty acids. The rates of soil-applied $\mathrm{N}$ were selected to provide a range of yield environments and greenness differences to determine the utility of a chlorophyll meter to help make recommendations to farmers. A typical $\mathrm{N}$ application rate is $169 \mathrm{~kg} \mathrm{~N} \mathrm{ha}^{-1}$ while a $337 \mathrm{~kg} \mathrm{ha}^{-1}$ amount was selected so $\mathrm{N}$ was not limiting. The low rate was selected to help determine a yield increase from the enhanced efficiency foliar $\mathrm{N}$ source.

The 30-0-0-0 was a slowly available foliar $\mathrm{N}$ source that was a blend of methylene urea, triazone, and urea (Nitamin, Koch Fertilizer, LLC., Wichita, Kansas). Soil-applied N rates provided for low-, medium-, and high-yield environments that may respond differently to foliar $\mathrm{N}$ applications. Foliar fungicide and 30-0-0-0 treatments were applied on 12 July 2010 and 8 July 2011 at Novelty, and 13 July 2010 and 15 July 2011 at Albany when corn was at the VT stage of development (Ritchie et al., 1993). Foliar fertilizer and fungicide treatments were applied with a $\mathrm{CO}_{2}$-propelled hand boom calibrated to deliver $28 \mathrm{~L} \mathrm{ha}^{-1}$. Field and management information is reported in Table 1. Supplemental irrigation was scheduled using the Woodruff chart (Henggler, 2008) so water was not a limiting factor for the different $\mathrm{N}$ amounts.

Corn injury from 0 (no visual crop injury) to $100 \%$ (complete crop death) was evaluated 7 and 14 days after 
treatment (DAT) based on the combined visual effects of foliar treatments on necrosis, chlorosis, and stunting. The severity of common rust, northern corn leaf blight, and grey leaf spot was rated on a scale of 0 (no disease) to $100 \%$ (complete infestation) at 0 and 42 DAT. Chlorophyll meter readings for 10 ear leaves plot ${ }^{-1}$ determining $^{-}$ $\mathrm{N}$ deficiency (Zhang et al., 2008) were recorded using a Minolta SPAD-502 (Konica Minolta Optics, Inc.) at VT. The SPAD meter was used determine absolute ear leaf greenness differences among treatments at the time of application (0 DAT) and 28 DAT. The two center rows were harvested (Wintersteiger Delta, Salt Lake City, UT at Novelty and Massey 8, Kincaid Equipment Manufacturing, Haven, KS at Albany) for yield, measured and then converted to $150 \mathrm{~g} \mathrm{~kg}^{-1}$ moisture prior to analysis. Grain samples were collected from each plot and ten subsamples analyzed for protein and starch concentration with a Foss Infratec 1241 (Eden Prairie, MN) near infrared spectrometer using established calibrations (Paulsen et al., 2003; Paulsen \& Singh, 2004; Singh et al., 2005). Grain samples with symptoms of diplodia (Stenocarpella maydis) (Flett et al., 2001), confirmed with the University of Missouri Plant Diagnostic Clinic, were quantified as the number of grains in the harvested sample of 100 seeds and converted to a percentage of seeds with the disease. Diplodia, which can affect marketability of corn, results in light kernels that generally have a low test weight; they are evaluated as damaged kernels from a screened grain sample (Woloshuk and Wise, 2008). All data were subjected to ANOVA and means separated using Fisher's protected LSD at $P=0.05$ or 0.1 . Data were combined over factors and locations when appropriate, as indicated by the analysis of variance.
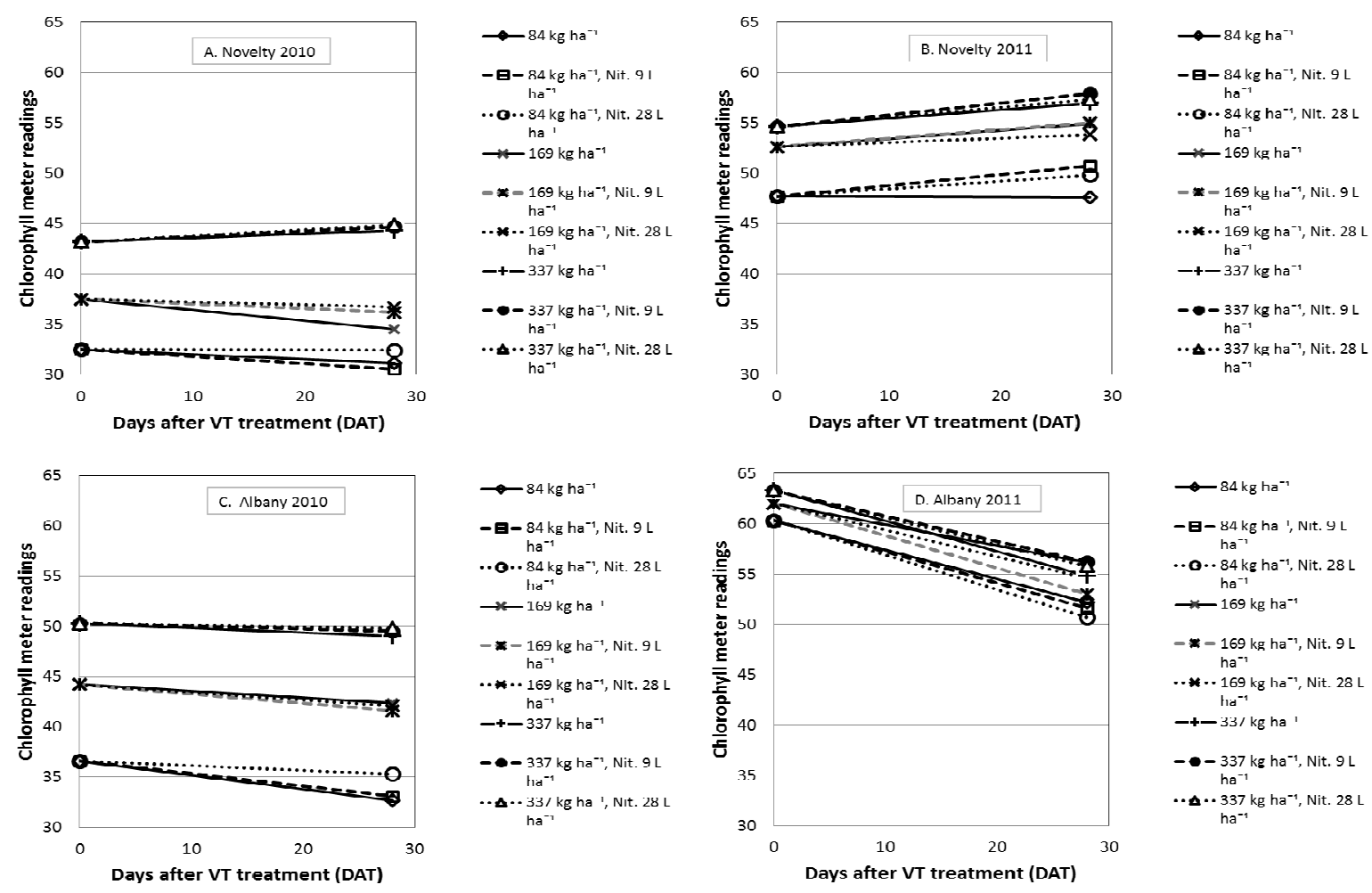

Figure 1. Chlorophyll meter readings at the time of application [0 days after VT treatment (DAT)] and 28 DAT for soil applied $\mathrm{N}$ treatments $\left(84,169\right.$, or $\left.337 \mathrm{~kg} \mathrm{~N} \mathrm{ha}^{-1}\right)$ and 30-0-0-0 (Nit.) rates $\left(0,1\right.$ or $\left.3 \mathrm{~L} \mathrm{ha}^{-1}\right)$ at Novelty (2010 and 2011) and Albany (2010 and 2011). Data were combined over pyraclostrobin treatments. LSD $(P=0.1)$ is 1 for the 28 DAT chlorophyll meter readings 
Table 1. Field and management information at Novelty and Albany in 2010 and 2011

\begin{tabular}{|c|c|c|c|c|}
\hline \multirow{2}{*}{ Management information } & \multicolumn{2}{|c|}{ Novelty } & \multicolumn{2}{|c|}{ Albany } \\
\hline & 2010 & 2011 & 2010 & 2011 \\
\hline Previous crop & Soybean & Soybean & Soybean & Soybean \\
\hline Hybrid & DKC63-42 VT3 & DKC63-42 VT3 & DKC63-42 VT3 & Pioneer 33D49 \\
\hline Planting date & 13 Apr. & 1 Apr. & 26 Apr. & 3 May \\
\hline Seeding rate (seeds ha $\left.{ }^{-1}\right)$ & 79,000 & 76,000 & 73,000 & 73,000 \\
\hline Harvest date & 30 Sept. & 12 Sept. & 19 Oct. & 26 Sept. \\
\hline Soil series ${ }^{\dagger}$ & Putnam silt loam & Putnam silt loam & Grundy silt loam & Grundy silt loam \\
\hline Maintenance fertilizer $\left(\mathrm{kg} \mathrm{ha}^{-1}\right)$ & $\begin{array}{l}13 \text { Apr., MAP } \\
\text { 36-180-337 (N-P-K) }\end{array}$ & NA & $\begin{array}{l}15 \text { Apr., DAP 20-52-90 } \\
\text { (N-P-K) }\end{array}$ & NA \\
\hline Ammonium nitrate & $\begin{array}{l}7 \text { May, Between-row at } \\
74,169 \text {, or } 337 \mathrm{~kg} \mathrm{~N}^{-1}\end{array}$ & $\begin{array}{l}18 \text { May, Between-row at } \\
74,169 \text {, or } 337 \mathrm{~kg} \mathrm{~N}^{-1}\end{array}$ & $\begin{array}{l}26 \text { May, Between-row at } \\
74,169 \text {, or } 337 \mathrm{~kg} \mathrm{~N}^{-1}\end{array}$ & $\begin{array}{l}6 \text { May, Between-row at } 74 \text {, } \\
169 \text {, or } 337 \mathrm{~kg} \mathrm{~N} \mathrm{ha}^{-1}\end{array}$ \\
\hline \multicolumn{5}{|l|}{ Weed management ${ }^{\S}$} \\
\hline Pre-emergence (rate) & $\begin{array}{l}15 \text { Apr., Atrazine } \\
\left(2.2 \mathrm{~kg} \text { ai ha }{ }^{-1}\right) \\
+ \text { dimethenamid-P } \\
\left(1.1 \mathrm{~kg} \text { ai ha }{ }^{-1}\right)\end{array}$ & $\begin{array}{l}13 \text { Apr., S-metolachlor }(1.9 \\
\left.\mathrm{kg} \text { ai } \mathrm{ha}^{-1}\right)+ \text { atrazine }(0.7 \\
\left.\mathrm{kg} \text { ai ha }{ }^{-1}\right)+ \text { mesotrione } \\
\left(0.2 \mathrm{~kg} \mathrm{ai} \mathrm{ha}^{-1}\right)\end{array}$ & $\begin{array}{l}27 \text { Apr., S-metolachlor }(2.4 \\
\left.\text { kg ai ha }{ }^{-1}\right)+ \text { atrazine }(0.9 \mathrm{~kg} \\
\left.\text { ai ha }{ }^{-1}\right)+ \text { mesotrione }(0.2 \mathrm{~kg} \\
\left.\text { ai ha }{ }^{-1}\right)\end{array}$ & $\begin{array}{l}3 \text { May, S-metolachlor }(2.4 \\
\left.\mathrm{kg} \text { ai ha }{ }^{-1}\right)+ \text { atrazine }(0.9 \\
\left.\mathrm{kg} \text { ai ha }{ }^{-1}\right)+ \text { mesotrione } \\
\left(0.2 \mathrm{~kg} \text { ai ha } \mathrm{ha}^{-1}\right)\end{array}$ \\
\hline Postemergence (rate) & $\begin{array}{l}22 \text { June, Glyphosate } \\
\left(1.4 \mathrm{~kg} \mathrm{ai} \mathrm{ha}^{-1}\right)+\text { DAS } \\
\left(0.02 \mathrm{~kg} \mathrm{~L}^{-1}\right)\end{array}$ & NA & NA & NA \\
\hline Disease management & $\begin{array}{l}\text { Pyraclostrobin }+/- \\
30-0-0-0\end{array}$ & Pyraclostrobin +/- 30-0-0-0 & Pyraclostrobin +/- 30-0-0-0 & Pyraclostrobin $+/-30-0-0-0$ \\
\hline Date, time & 12 July, 1700 to $2100 \mathrm{~h}$ & 8 July, 1000 to $1300 \mathrm{~h}$ & 13 July, 1100 to $1600 \mathrm{~h}$ & 15 , July 800 to $1100 \mathrm{~h}$ \\
\hline Air temperature $\left({ }^{\circ} \mathrm{C}\right)$ & $22-28$ & $26-29$ & $29-32$ & $28-31$ \\
\hline Relative humidity (\%) & $63-83$ & $62-70$ & $61-77$ & $66-83$ \\
\hline Wind speed ( $\mathrm{km} \mathrm{hr}^{-1}$, direction) & $1.6-4.8, \mathrm{E}$ & $0-1.6, \mathrm{~W}$ & $4.8-6.4, \mathrm{~S}$ & $3.2-8.0, \mathrm{~S}$ \\
\hline Corn plant height (m) & $1.8-2.4$ & $2.3-2.5$ & $2.1-2.7$ & $2.2-3.0$ \\
\hline Leaf moisture & Dry & Dry & Dry & Dry \\
\hline
\end{tabular}

Note. ${ }^{\dagger}$ : Putnam silt loam is loam (Fine, smectitic, mesic, Mollic Albaqualfs) and Grundy silt loam (fine, montmorillonitic, mesic Aquic Argiudolls);

\$: Abbreviations: DAP, diammonium phosphate; DAS, diammonium sulfate; MAP, monoammonium phosphate; and NA, None applied;

\$: $\quad$ 2-chloro-4-ethylamino-6-isopropylamino-s-traizine; dimethenamid-P, (S)-2chloro-N-[(1-methyl-2-methoxy)ethyl]-N-(2,4-dimethyl-thien-3-yl)acetamide; glyphosate, $\mathrm{N}$-(phosphonomethyl)glycine; mesotrione, 2-[4-(methylsulfonyl)-2-nitrobenzoyl]-1,3-cyclohexanedione; and S-metolachlor, acetamide, 2-chloro-N-(2-ethyl-6-methylphenyl)-N-(2-methoxy-1-methylethyl)-,(S).

\section{Results and Discussion}

In 2010, rainfall at both locations was extensive at $445 \mathrm{~mm}$ above the previous 10 -year average (Nelson and Meinhardt, 2011). Ammonium nitrate was soil-applied approximately one month after planting to increase efficiency of applied $\mathrm{N}$ (Table 1). However, conditions during the growing season favored extensive $\mathrm{N}$ loss. Corn plant population at harvest was 64,200 to $69,200 \mathrm{ha}^{-1}$ at both locations (Table 2). Disease severity was less than $1 \%$ at VT when treatments were applied (0 DAT), and no detectable differences were observed for the low- (84 $\left.\mathrm{kg} \mathrm{N} \mathrm{ha}{ }^{-1}\right)$, medium- (169 $\left.\mathrm{kg} \mathrm{N} \mathrm{ha}^{-1}\right)$, and high-yield environments (337 kg N ha ${ }^{-1}$ ) (Table 3). Chlorophyll meter readings indicated expected differences among soil-applied $\mathrm{N}$ rates at the time of the foliar VT applications (Table 3, Figure 1). In 2010, the Albany site probably lost less $\mathrm{N}$ and so was greener than Novelty. In 2011, both sites had higher relative initial chlorophyll meter readings (Figure 1). It was expected that the $337 \mathrm{~kg} \mathrm{~N} \mathrm{ha}^{-1}$ rate would be in the low-response range to additional N (Scharf et al., 2006), and that $\mathrm{N}$ would not be limiting. However, differing $\mathrm{N}$ rates provided different yielding environments that may respond differently to slow-release foliar $\mathrm{N}$ or pyraclostrobin application. Based upon previous research from V10 to R1 (Scharf et al., 2006), 
absolute chlorophyll meter readings at VT in 2010 indicated that an addition of 146 to $202 \mathrm{~kg} \mathrm{~N} \mathrm{ha}^{-1}, 112$ to 146 $\mathrm{kg} \mathrm{N} \mathrm{ha}{ }^{-1}$, and 51 to $101 \mathrm{~kg} \mathrm{~N} \mathrm{ha}^{-1}$ was recommended for the soil-applied rates of $84 \mathrm{~kg} \mathrm{~N} \mathrm{ha}^{-1}, 169 \mathrm{~kg} \mathrm{~N} \mathrm{ha}^{-1}$, and $337 \mathrm{~kg} \mathrm{~N} \mathrm{ha}^{-1}$, respectively. Since rainfall was $132 \mathrm{~mm}$ greater than the 10 -year average in the spring (Nelson and Meinhardt, 2011), we probably experienced greater gaseous $\mathrm{N}$ loss on these soils with poor internal drainage (Nash et al., 2012, 2015). In 2011, the plants needed less than $28 \mathrm{~kg} \mathrm{~N}^{-1}$ based on the chlorophyll readings at the time of application. The 30-0-0-0 rates evaluated in this research were applied at 3.5 and $10.4 \mathrm{~kg}$ $\mathrm{N} \mathrm{ha}^{-1}$ for the 9 and $28 \mathrm{~L} \mathrm{ha}^{-1}$ rates, respectively.

Table 2. Corn plant population at harvest and grain yield for the low- $\left(84 \mathrm{~kg} \mathrm{~N} \mathrm{ha}^{-1}\right)$, medium- $\left(169 \mathrm{~kg} \mathrm{~N} \mathrm{ha}^{-1}\right.$ at Novelty and Albany), and high-yield environments $\left(337 \mathrm{~kg} \mathrm{~N} \mathrm{ha}^{-1}\right)$. Main effects were presented in the absence of significant interactions

\begin{tabular}{|c|c|c|c|c|c|}
\hline \multirow{3}{*}{ Treatment (rates) } & \multirow{3}{*}{ Plant population } & \multicolumn{4}{|c|}{ Grain yield } \\
\hline & & \multirow{2}{*}{ Low yield } & \multicolumn{2}{|c|}{ Medium yield } & \multirow{2}{*}{ High yield } \\
\hline & & & Albany & Novelty & \\
\hline & No. ha $^{-1}$ & \multicolumn{4}{|c|}{------------------ Mg ha" } \\
\hline Non-treated & 65,000 & 7.28 & 8.10 & 9.35 & 10.17 \\
\hline $30-0-0-0\left(9 \mathrm{~L} \mathrm{ha}^{-1}\right)$ & 64,200 & 7.09 & 7.91 & 9.54 & 10.55 \\
\hline $30-0-0-0\left(28 \mathrm{~L} \mathrm{ha}^{-1}\right)$ & 69,200 & 7.34 & 8.41 & 8.91 & 10.11 \\
\hline $\operatorname{LSD}(P=0.1)^{\dagger}$ & NS & NS & NS & 0.44 & 0.31 \\
\hline Non-treated & 66,500 & 7.34 & 8.22 & 9.16 & 9.85 \\
\hline Pyraclostrobin at $0.055 \mathrm{~kg}$ ai ha ${ }^{-1}+30-0-0-0^{+}$ & 64,700 & 7.09 & 8.22 & 9.23 & 10.23 \\
\hline $30-0-0-0+$ Pyraclostrobin $\left(0.055 \mathrm{~kg}\right.$ ai ha $\left.{ }^{-1}\right)$ & 68,200 & 7.34 & 8.03 & 9.48 & 10.42 \\
\hline Pyraclostrobin at $0.11 \mathrm{~kg}$ ai $\mathrm{ha}^{-1}+30-0-0-0$ & 68,700 & 7.16 & 8.10 & 9.23 & 10.55 \\
\hline $\operatorname{LSD}(P=0.1)^{\S}$ & NS & NS & NS & NS & 0.38 \\
\hline
\end{tabular}

Note. $^{\dagger}$ : Data were averaged over pyraclostrobin treatments, years (2010 and 2011) and locations (Albany and Novelty, except the medium-yield environment);

$\$$ : Listed order is the mixing order of these treatments. All treatments with pyraclostrobin included non-ionic surfactant at $0.25 \%$ vol./vol;

§: Data were averaged over 30-0-0-0 treatments, years (2010 and 2011) and locations (Albany and Novelty, except the medium-yield environment).

Absolute chlorophyll meter readings at VT generally remained similar or decreased slightly over time in the absence of additional N (Figure 1), a finding similar to that of Scharf et al. (2006). Chlorophyll meter readings varied by $\mathrm{N}$ rate at the time 30-0-0-0 was applied (0 DAT), similar to other studies evaluating $\mathrm{N}$ rates and yield responses (Scharf et al., 2006; Zhang et al., 2008; Ziadi et al., 2008). Chlorophyll meter values 28 DAT indicated increased ear-leaf greenness with $30-0-0-0$ at $28 \mathrm{~L} \mathrm{ha}^{-1}$ compared to chlorophyll content at application (0 DAT) in some instances. Limited differences appeared between the 0 and 28 DAT readings when 30-0-0-0 was applied at 0 or $9 \mathrm{~L} \mathrm{ha}^{-1}$. Although differences in chlorophyll content were detected based on the preplant rates, changes in leaf greenness due to low $\mathrm{N}$ rates were inconsistent based on chlorophyll meter readings 28 DAT using 30-0-0-0. Similarly, Zhang et al. (2008) had difficulty predicting intermediate $\mathrm{N}$ deficiencies with certainty of a yield impact until late in the season. Based on the chlorophyll meter values, yield differences were expected for the 28 $\mathrm{L} \mathrm{ha}^{-1}$ rate of 30-0-0-0; however, this was not the case (Table 2). The foliar fertilizer, 30-0-0-0, at $28 \mathrm{~L} \mathrm{ha}^{-1}$ injured corn 3 to $4 \%$ (Table 4), which probably negated any yield increase from this treatment. Although foliar feeding corn with urea $\mathrm{N}$ has caused marginal leaf necrosis in other studies, yields were similar to the same amount applied at a side dress timing (Foy et al., 1953). There was no interaction among the factors evaluated with pyraclostrobin on crop injury while the main factor of pyraclostrobin had no significant effect $(P=0.57)$ on crop injury. The addition of surfactant with pyraclostrobin may have increased the rate of urea absorption and caused more injury (Foy et al., 1953). 
Table 3. Chlorophyll meter readings at Novelty and Albany in 2010 and 2011, and severity of diseases for preplant $\mathrm{N}$ rates at the time VT treatments were applied. Data were combined over foliar fertilizer and fungicide treatments

\begin{tabular}{|c|c|c|c|c|c|c|c|c|}
\hline \multirow[b]{2}{*}{ Preplant $\mathrm{N}$ rates } & \multicolumn{5}{|c|}{ Chlorophyll meter } & \multicolumn{3}{|c|}{ Severity of disease $^{\dagger}$} \\
\hline & $\begin{array}{l}\text { Novelty } \\
2010\end{array}$ & $\begin{array}{l}\text { Albany } \\
2010\end{array}$ & $\begin{array}{l}\text { Novelty } \\
2011\end{array}$ & $\begin{array}{l}\text { Albany } \\
2011\end{array}$ & Average & $\begin{array}{l}\text { Grey leaf } \\
\text { spot }\end{array}$ & $\begin{array}{l}\text { Common } \\
\text { rust }\end{array}$ & $\begin{array}{l}\text { Northern corn } \\
\text { leaf blight }\end{array}$ \\
\hline $\mathrm{kg} \mathrm{N} \mathrm{ha}^{-1}$ & \multicolumn{5}{|c|}{ - --10 } & \multicolumn{3}{|c|}{ 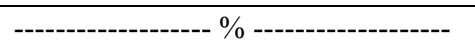 } \\
\hline 84 & 32.5 & 36.6 & 47.7 & 60.3 & 44.3 & $<1$ & 0 & $<1$ \\
\hline 169 & 37.3 & 44.2 & 52.6 & 62.0 & 49.0 & $<1$ & 0 & $<1$ \\
\hline 337 & 43.2 & 50.3 & 54.6 & 63.0 & 52.8 & $<1$ & 0 & $<1$ \\
\hline $\operatorname{LSD}(P=0.1)$ & \multicolumn{4}{|c|}{ 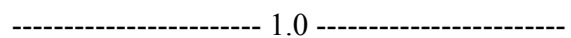 } & 0.5 & NS & NS & NS \\
\hline
\end{tabular}

Note. ${ }^{\dagger}$ : Common rust (Puccinia sorghi); grey leaf spot (Cercospora zeae-maydis); and northern corn leaf blight (Exserohilum turcicum).

Table 4. Corn injury as affected by preplant $\mathrm{N}$ management and foliar 30-0-0-0 rate $14 \mathrm{~d}$ after treatment (DAT). Data were combined over the four site-years and pyraclostrobin treatments.

\begin{tabular}{|c|c|c|c|}
\hline Preplant $\mathrm{N}$ rates & $30-0-0-0$ at $0 \mathrm{~L} \mathrm{ha}^{-1}$ & $30-0-0-0$ at $9 \mathrm{~L} \mathrm{ha}^{-1}$ & $30-0-0-0$ at $28 \mathrm{~L} \mathrm{ha}^{-1}$ \\
\hline $\mathrm{kg} \mathrm{ha}^{-1}$ & \multicolumn{3}{|c|}{ 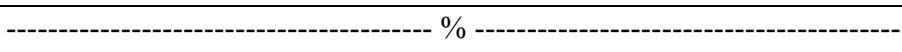 } \\
\hline 84 & 0 & 1 & 4 \\
\hline 269 & 0 & 1 & 4 \\
\hline 337 & 0 & 1 & 3 \\
\hline $\operatorname{LSD}(P=0.05)$ & \multicolumn{3}{|c|}{----------------------------------------------- 1 ---------------------------------------- } \\
\hline
\end{tabular}

There was no effect of 30-0-0-0 at 9 to $28 \mathrm{~L} \mathrm{ha}^{-1}$ on corn yield in low- (soil-applied $\mathrm{N}$ at $84 \mathrm{~kg} \mathrm{ha}^{-1}$ at Novelty and Albany in 2010 and 2011) or medium-yield environments (soil-applied $\mathrm{N}$ at $169 \mathrm{~kg} \mathrm{ha}^{-1}$ at Novelty and Albany in 2010 and 2011) (Table 2). This indicated that too much $\mathrm{N}$ was needed to overcome $\mathrm{N}$ deficiency with a 30-0-0-0 application. Foliar-applied $\mathrm{N}$ at $40 \mathrm{~kg} \mathrm{~N}$ ha $^{-1}$ was no substitute for soil-applied $\mathrm{N}$ for attaining high yields (Tomar et al., 1988). A rescue $\mathrm{N}$ application (Nelson et al., 2011) was probably necessary in this situation, though $\mathrm{N}$ applications at silking stage may not always attain the crop's full yield potential (Scharf et al., 2002). However, rescue $\mathrm{N}$ applications of broadcast-applied foliar urea ammonium nitrate at high rates are not recommended due to extensive injury to corn causing reduced yield. But an application of urea could minimize yield loss (Nelson et al., 2011). At Novelty in a medium-yield environment, grain yields were reduced 0.44 to $0.63 \mathrm{Mg} \mathrm{ha}^{-1}$ with 30-0-0-0 at $28 \mathrm{~L} \mathrm{ha}^{-1}$ compared to 30-0-0-0 at 0 or $9 \mathrm{~L} \mathrm{ha}^{-1}$ (Table 2). The reduction probably stemmed from increased crop injury from the 30-0-0-0 application (Table 4). Leaf injury usually occurs shortly after applying foliar $\mathrm{N}$ and results in necrotic lesions (Gamble and Emino, 1987). Other researchers have reported yield reductions (6.7\%) when applying $\mathrm{N}$ near silking stage (Harder et al., 1982). In a high yield-environment (soil-applied $\mathrm{N}$ at $337 \mathrm{~kg} \mathrm{ha}^{-1}$ at Novelty and Albany), 30-0-0-0 at $9 \mathrm{~L} \mathrm{ha}^{-1}$ increased grain yields $0.38 \mathrm{Mg} \mathrm{ha}^{-1}$ (3.7\%) compared to the non-treated control (Table 2). Similarly, pyraclostrobin increased yield 0.38 to $0.7 \mathrm{Mg} \mathrm{ha}^{-1}$ (3.9 to $7.1 \%$ ) compared to the non-treated control in a high-yield environment (>9.6 $\left.\mathrm{Mg} \mathrm{ha}^{-1}\right)$. This research indicated no significant effect of mixing order on corn yield when 30-0-0-0 was applied at $9 \mathrm{~L} \mathrm{ha}^{-1}$ and pyraclostrobin was applied at $0.055 \mathrm{~kg}$ ai ha ${ }^{-1}$, but yields were $3 \%$ greater with pyraclostrobin at $0.11 \mathrm{~kg}$ ai ha ${ }^{-1}$ compared to $0.055 \mathrm{~kg}$ ai ha ${ }^{-1}$ when mixed with $30-0-0-0$ in the same order. 
Table 5. Severity of grey leaf spot $42 \mathrm{~d}$ after treatment as affected by preplant $\mathrm{N}$ and pyraclostrobin, and 30-0-0-0 rate and pyraclostrobin. Data were combined over four-site years and main effects presented

\begin{tabular}{|c|c|c|c|c|c|c|}
\hline \multirow{2}{*}{ Fungicide treatment ${ }^{\dagger}$} & \multicolumn{3}{|c|}{ Preplant $\mathrm{N}$ rate $\left(\mathrm{kg} \mathrm{N} \mathrm{ha}^{-1}\right)$} & \multicolumn{3}{|c|}{$30-0-0-0$ rate $\left(\mathrm{L} \mathrm{ha}^{-1}\right)$} \\
\hline & $\overline{84}$ & 169 & 337 & $\overline{0}$ & 9 & 28 \\
\hline & \multicolumn{6}{|c|}{--ority of disease (\%) --- Severio } \\
\hline Non-treated & 3 & 4 & 5 & 4 & 4 & 4 \\
\hline Pyraclostrobin at $0.055 \mathrm{~kg}$ ai $\mathrm{ha}^{-1}+30-0-0-0$ & 3 & 3 & 4 & 3 & 3 & 4 \\
\hline $30-0-0-0+$ Pyraclostrobin at $0.055 \mathrm{~kg}$ ai ha ${ }^{-1}$ & 3 & 4 & 4 & 3 & 3 & 4 \\
\hline Pyraclostrobin at $0.11 \mathrm{~kg}$ ai ha ${ }^{-1}+30-0-0-0$ & 3 & 4 & 4 & 3 & 3 & 4 \\
\hline $\operatorname{LSD}(P=0.1)$ & \multicolumn{3}{|c|}{ 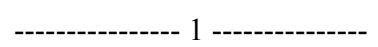 } & \multicolumn{3}{|c|}{ 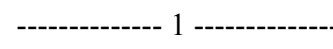 } \\
\hline
\end{tabular}

Note. ${ }^{\dagger}$ : Listed order is the mixing order of these treatments. All treatments with pyraclostrobin included non-ionic surfactant at $0.25 \%$ vol./vol.

Soil-applied N, foliar-applied 30-0-0-0, pyraclostrobin, and site-year affected the severity of foliar diseases in this study. The severity of grey leaf spot was less than $5 \%$ at 42 DAT (Table 5). Its severity increased slightly as the soil-applied $\mathrm{N}$ rate increased from 84 to $337 \mathrm{~kg} \mathrm{~N} \mathrm{ha}^{-1}$ and the $30-0-0-0$ rate increased from 9 to $28 \mathrm{~L} \mathrm{ha}^{-1}$. Pyraclostrobin generally decreased the severity of grey leaf spot in a high-yield environment $(337 \mathrm{~kg}$ preplant $\mathrm{N}$ $\mathrm{ha}^{-1}$ ), and with 30-0-0-0 at $9 \mathrm{~L} \mathrm{ha}^{-1}$ or in the absence of 30-0-0-0. Northern corn leaf blight and common rust severity were affected by site-years, and interactions among factors were observed (Tables 6 and 7). In 2010, the severity of northern corn leaf blight was less than 2\% at Albany and Novelty (Tables 6 and 7). In 2011, its severity increased slightly as the rate of soil applied $\mathrm{N}$ increased at Novelty and Albany (Table 6), but severity increased 3 to $6 \%$ at Novelty and 1 to $2 \%$ at Albany as the rate of 30-0-0-0 increased (Table 7). Although this study found only minor disease severity differences between $\mathrm{N}$ treatments, probably due to increased injury caused by 30-0-0-0 at $28 \mathrm{~L} \mathrm{ha}^{-1}$, other research saw no effect of $\mathrm{N}$ management on the severity of northern corn leaf blight (Bair et al., 1990). Foliar-applied fertilizer has caused lesions that resulted in desiccation of epidermal cells (Gamble \& Emino, 1987; Shetley et al., 2015), which may allow greater infection of leaf tissue when foliar disease is present. In 2011, common rust was not present at Novelty or Albany, and it was less than $2 \%$ at Novelty in 2010 (Tables 6 and 7). As preplant $\mathrm{N}$ rates increased and 30-0-0-0 rates increased to $28 \mathrm{~L} \mathrm{ha}^{-1}$, the severity of common rust increased slightly (Table 7).

Pyraclostrobin did not affect $(P=0.95)$ grain moisture (data not presented). However, grain moisture increased as preplant $\mathrm{N}$ rates increased (Table 8 ) and decreased as 30-0-0-0 rates increased (Table 9). This differs from a previous study showing higher grain moisture content of corn treated with pyraclostrobin (Nelson \& Meinhardt, 2011). At Novelty, grain disease (diplodia) symptoms increased $4 \%$ as the preplant $\mathrm{N}$ rate increased (Table 8 ) and increased slightly as the 30-0-0-0 rate increased in 2010 (Table 9), but in 2011 at Novelty and Albany no differences were observed. Pyraclostrobin did not affect grain disease $(P=0.27)$, similar to other research (Nelson \& Meinhardt, 2011). An interaction occurred between 30-0-0-0 rates and soil applied $\mathrm{N}$ rates on protein concentration with an 11 to $13 \mathrm{~g} \mathrm{~kg}^{-1}$ increase as the soil applied $\mathrm{N}$ rate increased. Protein concentration increased $2 \mathrm{~g} \mathrm{~kg}^{-1}$ with 30-0-0-0 as the rate increased from 0 to $28 \mathrm{~L} \mathrm{ha}^{-1}$ in a high-yield environment $(337 \mathrm{~kg} \mathrm{~N}$ $\left.\mathrm{ha}^{-1}\right)$, but pyraclostrobin did not affect protein concentrations $(P=0.36)$. Similarly, a foliar fungicide showed no effect on wheat protein concentrations when combined with a foliar $\mathrm{N}$ application (Kelley, 1993). A significant interaction occurred between pyraclostrobin and 30-0-0-0 rates $(P=0.04)$ on starch concentration, but only slight differences in starch concentrations were observed (Table 9). 
Table 6 . Severity of northern corn leaf blight severity as and common rust severity as affected by preplant $\mathrm{N}$ rate and location $42 \mathrm{~d}$ after treatment

\begin{tabular}{|c|c|c|c|c|c|c|c|c|c|c|c|c|c|c|c|c|}
\hline \multirow{3}{*}{ Preplant rate } & \multicolumn{4}{|c|}{ Northern corn leaf blight } & \multicolumn{12}{|c|}{ Common rust } \\
\hline & \multirow{2}{*}{$\begin{array}{l}\text { Novelty } \\
2010\end{array}$} & \multirow{2}{*}{$\begin{array}{l}\text { Novelty } \\
2011\end{array}$} & \multirow{2}{*}{$\begin{array}{l}\text { Albany } \\
2010\end{array}$} & \multirow{2}{*}{$\begin{array}{l}\text { Albany } \\
2011\end{array}$} & \multicolumn{3}{|c|}{ Novelty 2010} & \multicolumn{3}{|c|}{ Novelty 2011} & \multicolumn{3}{|c|}{ Albany 2010} & \multicolumn{3}{|c|}{ Albany 2011} \\
\hline & & & & & $0^{\dagger}$ & 9 & 28 & 0 & 9 & 28 & 0 & 9 & 28 & 0 & 9 & 28 \\
\hline$\left(\mathrm{kg} \mathrm{N} \mathrm{ha}^{-1}\right)$ & ------- & 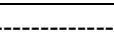 & & 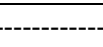 & -54 & EIIt & of $d$ & (\% & & & & & & $\ldots$ & - & ---- \\
\hline 84 & 0 & 7 & 1 & 3 & 1 & 1 & 2 & 0 & 0 & 0 & 2 & 2 & 2 & 0 & 0 & 0 \\
\hline 169 & 1 & 8 & 1 & 4 & 1 & 1 & 2 & 0 & 0 & 0 & 3 & 2 & 2 & 0 & 0 & 0 \\
\hline 337 & 1 & 8 & 1 & 4 & 1 & 2 & 2 & 0 & 0 & 0 & 7 & 4 & 2 & 0 & 0 & 0 \\
\hline
\end{tabular}

Note. ${ }^{\dagger}$ : The amount of 30-0-0-0 in that was applied in $\mathrm{L} \mathrm{ha}^{-1}$.

Table 7. Effect of pyraclostrobin treatment, location, and 30-0-0-0 rate on the severity of northern corn leaf blight and common rust $42 \mathrm{~d}$ after treatment.

\begin{tabular}{|c|c|c|c|c|c|c|c|c|c|c|c|c|c|c|c|c|c|c|c|c|c|c|c|c|c|}
\hline \multirow{3}{*}{\multicolumn{2}{|c|}{$\begin{array}{l}\text { Fungicide } \\
\text { treatment }^{\dagger}\end{array}$}} & \multicolumn{12}{|c|}{ Northern corn leaf blight } & \multicolumn{12}{|c|}{ Common rust } \\
\hline & & \multicolumn{3}{|c|}{$\begin{array}{l}\text { Novelty } \\
2010\end{array}$} & \multicolumn{3}{|c|}{$\begin{array}{l}\text { Novelty } \\
2011\end{array}$} & \multicolumn{3}{|c|}{$\begin{array}{l}\text { Albany } \\
2010\end{array}$} & \multicolumn{3}{|c|}{$\begin{array}{l}\text { Albany } \\
2011\end{array}$} & \multicolumn{3}{|c|}{$\begin{array}{l}\text { Novelty } \\
2010\end{array}$} & \multicolumn{3}{|c|}{$\begin{array}{l}\text { Novelty } \\
2011\end{array}$} & \multicolumn{3}{|c|}{$\begin{array}{l}\text { Albany } \\
2010\end{array}$} & \multicolumn{3}{|c|}{$\begin{array}{l}\text { Albany } \\
2011\end{array}$} \\
\hline & & $0^{\ddagger}$ & 9 & 28 & 0 & 9 & 28 & 0 & 9 & 28 & 0 & 9 & 28 & 0 & 9 & 28 & 0 & 9 & 28 & 0 & 9 & 28 & 0 & 9 & 28 \\
\hline & & - & --- & ---- & 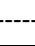 & -- & -י--יר & 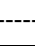 & 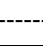 & ---- & 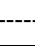 & $\mathrm{Se}$ & verit & ise & 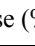 & ) & & & & --- & & & & - & \\
\hline Non-treated & & 0 & 1 & 1 & 8 & 9 & 12 & 1 & 1 & 1 & 3 & 4 & 5 & 2 & 2 & 2 & 0 & 0 & 0 & 3 & 3 & 3 & 0 & 0 & 0 \\
\hline $\begin{array}{l}\text { Pyraclostrobin } \\
0.055 \mathrm{~kg} \text { ai } \mathrm{ha}^{-1} \\
30-0-0-0\end{array}$ & $\begin{array}{l}\text { at } \\
+\end{array}$ & 0 & 0 & 1 & 6 & 6 & 10 & 1 & 1 & 1 & 3 & 3 & 5 & 1 & 1 & 2 & 0 & 0 & 0 & 2 & 2 & 4 & 0 & 0 & 0 \\
\hline $\begin{array}{l}30-0-0-0 \\
\text { Pyraclostrobin } \\
0.055 \mathrm{~kg} \text { ai ha }\end{array}$ & $\begin{array}{l}+ \\
\text { at }\end{array}$ & 0 & 0 & 1 & 6 & 6 & 12 & 1 & 1 & 2 & 3 & 3 & 4 & 1 & 1 & 2 & 0 & 0 & 0 & 2 & 2 & 4 & 0 & 0 & 0 \\
\hline $\begin{array}{l}\text { Pyraclostrobin } \\
0.11 \mathrm{~kg} \text { ai } \mathrm{ha}^{-1} \\
30-0-0-0\end{array}$ & $\begin{array}{l}\text { at } \\
+\end{array}$ & 0 & 1 & 1 & 5 & 5 & 11 & 1 & 1 & 1 & 3 & 3 & 4 & 1 & 1 & 2 & 0 & 0 & 0 & 2 & 2 & 5 & 0 & 0 & 0 \\
\hline $\operatorname{LSD}(P=0.1)$ & & & 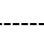 & --- & & - & ---1 & & & - & & - & & & & - & & & 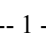 & --- & $\cdots$ & & & ---- & --- \\
\hline
\end{tabular}

Note. ${ }^{\dagger}$ : Listed order is the mixing order of these treatments. All treatments with pyraclostrobin included non-ionic surfactant at $0.25 \%$ vol./vol; ${ }^{*}$ : The amount of 30-0-0-0 in that was applied in $\mathrm{L} \mathrm{ha}^{-1}$.

Table 8. Effect of preplant $\mathrm{N}$ rate on grain moisture, disease (diplodia) at each site-year, and protein concentration for 30-0-0-0 rates. Data were combined over site-year in the absence of inteactions

\begin{tabular}{|c|c|c|c|c|c|c|c|c|}
\hline \multirow[b]{2}{*}{ Soil applied N } & \multirow{2}{*}{$\begin{array}{l}\text { Grain } \\
\text { moisture }\end{array}$} & \multicolumn{4}{|c|}{ Grain disease (diplodia) } & \multicolumn{3}{|c|}{ Protein concentration } \\
\hline & & $\begin{array}{l}\text { Novelty } \\
2010\end{array}$ & $\begin{array}{l}\text { Novelty } \\
2011\end{array}$ & $\begin{array}{l}\text { Albany } \\
2010\end{array}$ & $\begin{array}{l}\text { Albany } \\
2011\end{array}$ & $\begin{array}{l}0 \\
\mathrm{~L} \mathrm{ha}^{-1 \dagger}\end{array}$ & $\begin{array}{l}9 \\
\mathrm{~L} \mathrm{ha}^{-1}\end{array}$ & $\begin{array}{l}28 \\
\mathrm{~L} \mathrm{ha}^{-1}\end{array}$ \\
\hline$\left(\mathrm{kg} \mathrm{ha}^{-1}\right)$ & $\mathrm{g} \mathrm{kg}^{-1}$ & \multicolumn{4}{|c|}{ 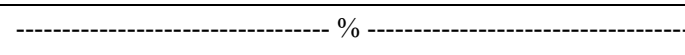 } & \multicolumn{3}{|c|}{-1-0--- $\mathrm{g} \mathrm{kg}^{-1}$} \\
\hline 84 & 201 & 5 & 0 & 2 & 0 & 73 & 72 & 73 \\
\hline 169 & 205 & 6 & 0 & 2 & 0 & 77 & 78 & 78 \\
\hline 337 & 207 & 9 & 0 & 2 & 0 & 84 & 85 & 86 \\
\hline $\operatorname{LSD}(P=0.05)$ & 3 & \multicolumn{4}{|c|}{ 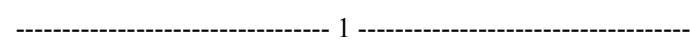 } & \multicolumn{3}{|c|}{----------------- 2 -------------. } \\
\hline
\end{tabular}

Note. ${ }^{\dagger}$ : The amount of 30-0-0-0 applied in $\mathrm{L} \mathrm{ha}^{-1}$. 
Table 9. Effect of 30-0-0-0 rates on grain moisture, disease (diplodia) at each site-year, and starch concentration for different pyraclostrobin applications

\begin{tabular}{|c|c|c|c|c|c|c|c|c|c|}
\hline \multirow[b]{2}{*}{$\begin{array}{l}30-0-0-0 \\
\text { rate }\end{array}$} & \multirow[b]{2}{*}{$\begin{array}{l}\text { Grain } \\
\text { moisture }\end{array}$} & \multicolumn{4}{|c|}{ Grain disease (diplodia) } & \multicolumn{4}{|c|}{ Starch concentration } \\
\hline & & $\begin{array}{l}\text { Novelty } \\
2010\end{array}$ & $\begin{array}{l}\text { Novelty } \\
2011\end{array}$ & $\begin{array}{l}\text { Albany } \\
2010\end{array}$ & $\begin{array}{l}\text { Albany } \\
2011\end{array}$ & $\begin{array}{l}\text { Non- } \\
\text { treated }\end{array}$ & $\begin{array}{l}\text { Pyraclostrobin } \\
\text { at } 0.055 \mathrm{~kg} \text { ai } \\
\mathrm{ha}^{-1}+30-0-0-0^{\dagger}\end{array}$ & $\begin{array}{l}30-0-0-0+ \\
\text { pyraclostrobin at } \\
0.055 \mathrm{~kg} \mathrm{ai} \mathrm{ha}^{-1}\end{array}$ & $\begin{array}{l}\text { Pyraclostrobin } \\
\text { at } 0.11 \mathrm{~kg} \text { ai } \\
\mathrm{ha}^{-1}+30-0-0-0\end{array}$ \\
\hline$\left(\mathrm{L} \mathrm{ha}^{-1}\right)$ & $\mathrm{g} \mathrm{kg}^{-1}$ & \multicolumn{4}{|c|}{ 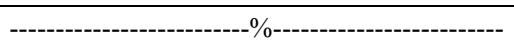 } & \multicolumn{4}{|c|}{ - } \\
\hline 0 & 206 & 6 & 0 & 2 & 0 & 730 & 731 & 729 & 730 \\
\hline 9 & 205 & 7 & 0 & 2 & 0 & 730 & 730 & 730 & 730 \\
\hline 28 & 203 & 7 & 0 & 2 & 0 & 731 & 729 & 730 & 729 \\
\hline $\begin{array}{l}\text { LSD } \\
(P=0.05)\end{array}$ & 3 & ------- & ------ & . & -------- & - & ---- & & - \\
\hline
\end{tabular}

Note. ${ }^{\dagger}$ : Listed order is the mixing order of these treatments. All treatments with pyraclostrobin included non-ionic surfactant at $0.25 \% \mathrm{vol} . / \mathrm{vol}$.

\section{Conclusions}

There was up to a $0.38 \mathrm{Mg} \mathrm{ha}^{-1}(3.7 \%)$ increase in grain yields with $30-0-0-0$ at $9 \mathrm{~L} \mathrm{ha}^{-1}$ in a high yield environment when chlorophyll meter readings at VT were greater than 45 in 2010, greater than 55 at Novelty in 2011, and greater than 63 at Albany in 2011. There was no effect of 30-0-0-0 at 9 or $28 \mathrm{~L} \mathrm{ha}^{-1}$ on corn yields in low- (soil applied $\mathrm{N}$ at $84 \mathrm{~kg} \mathrm{ha}^{-1}$ at Novelty and Albany in 2010 and 2011) or medium-yield environments (soil applied $\mathrm{N}$ at $169 \mathrm{~kg} \mathrm{ha}^{-1}$ at Novelty and Albany in 2010 and 2011). This indicated not only that too much $\mathrm{N}$ was needed to overcome $\mathrm{N}$ deficiency with an aerial 30-0-0-0 application combined with a fungicide application, but also that a rescue $\mathrm{N}$ application is generally recommended before VT to attain full yield potential. In a medium-yield environment at Novelty, grain yields decreased $0.44 \mathrm{Mg} \mathrm{ha}^{-1}$ with 30-0-0-0 at $28 \mathrm{~L} \mathrm{ha}^{-1}$, which was probably due to increased crop injury (3-4\%) from applying 30-0-0-0. Pyraclostrobin increased yields 0.38 to $0.7 \mathrm{Mg} \mathrm{ha}^{-1}$ (3.9 to $7.1 \%$ ) compared to the non-treated control in a high-yield environment $\left(>9.4 \mathrm{Mg} \mathrm{ha}^{-1}\right)$. This research indicated no significant effect of mixing order on corn response when 30-0-0-0 was applied at $9 \mathrm{~L}$ $\mathrm{ha}^{-1}$ and pyraclostrobin at $0.055 \mathrm{~g}_{\text {ai }} \mathrm{ha}^{-1}$. The severity of diseases in this study was $<12 \%$, depending on the treatment, and it was affected by $\mathrm{N}$ fertility, 30-0-0-0 rate, and fungicide management in some instances, depending on the location. Pyraclostrobin plus 30-0-0-0 at $9 \mathrm{~L} \mathrm{ha}^{-1}$ showed a yield benefit in high-yielding corn production environments.

\section{Acknowledgements}

The authors would like to thank Clinton Meinhardt and Randall Smoot for their technical support, and the Missouri Fertilizer and Agriculture Lime Board for their financial support of this research.

\section{References}

Bair, W., McGahen, J. H., \& Ayers, J. E. (1990). Effect of time and rate of nitrogen sidedress application on northern corn leaf blight severity and the associated yield loss. J. Prod. Agric., 3, 44-49. http://dx.doi.org/10.2134/jpa1990.0044

Bowen, K. L., \& Pedersen, W. L. (1988). Effects of propiconazole on Exserohilum turcicum in laboratory and field studies. Plant Dis., 72, 847-850. http://dx.doi.org/10.1094/PD-72-0847

Bradley, C. A., \& Ames, K. A. (2010). Effect of foliar fungicides on corn with simulated hail damage. Plant Dis., 94, 83-86. http://dx.doi.org/10.1094/PDIS-94-1-0083

Buchholz, D. D. (1992). Soil test interpretations and recommendations handbook. Department of Agronomy, University of Missouri, Columbia.

Conrath, U., Amoroso, G., Köhle, H., \& Sultemeyer, D. F. (2004). Non-invasive online detection of nitric oxide from plants and other organisms by mass spectroscopy. Plant J., 38, 1015-1022. http://dx.doi.org/10.1111/j.1365-313X.2004.02096.x

Dinnes, D. L., Karlen, D. L., Jaynes, D. B., Kaspar, T. C., Hatfield, J. L., Colvin, T. S., \& Cambardella, C. A. (2002). Nitrogen management strategies to reduce nitrate leaching in tile-drained midwestern soils. Agron. J., 94, 153-171. http://dx.doi.org/10.2134/agronj2002.1530 
Fageria, N. K., Barbosa Filho, M. P., Moreira, A., \& Guimaraes, C. M. (2009). Foliar fertilization of crop plants. J. Plant Nutrition, 32, 1044-1064. http://dx.doi.org/10.1080/01904160902872826

Ferguson, R. B., Shapiro, C. A., Hergert, G. W., Kranz, W. L., Klocke, N. L., \& Krull, D. H. (1991). Nitrogen and irrigation management practices to minimize nitrate leaching from irrigated corn. J. Prod. Agric., 4, 186-192. http://dx.doi.org/10.2134/jpa1991.0186

Flett, B. C., McLaren, N. W., \& Wehner, F. C. (2001). Incidence of Stenocarpella maydis ear rot of corn under crop rotation systems. Plant Dis., 85, 92-94. http://dx.doi.org/10.1094/PDIS.2001.85.1.92

Foy, C. D., Montenegro, G., \& Barber, S. A. (1953). Foliar feeding of corn with urea nitrogen. Soil Science Society of Am. J., 17, 387-390. http://dx.doi.org/10.2136/sssaj1953.03615995001700040022x

Gamble, P. E., \& Emino, E. R. (1987). Morphological and anatomical characterization of leaf burn in corn $\begin{array}{llllll}\text { induced from foliar-applied nitrogen. } & \text { Agron. }\end{array}$ http://dx.doi.org/10.2134/agronj1987.00021962007900010019x

Harder, H. J., Carlson, R. E., \& Shaw, R. H. (1982). Corn grain yield and nutrient response to foliar fertilizer $\begin{array}{llllll}\text { applied during } & \text { grain }\end{array}$ http://dx.doi.org/10.2134/agronj1982.00021962007400010027x

Hawkins, J. A., Sawyer, J. E., Barker, D. W., \& Lundvall, J. P. (2007). Using relative chlorophyll meter values to determine nitrogen application rates for corn. Agron. J., 99, 1034-1040. http://dx.doi.org/10.2134/agronj2006.0309

Henggler, J. (2008). University of Missouri Extension. Online. Retrieved February 8, 2010, from http://agebb.missouri.edu/irrigate/woodruff

Kelley, K. W. (1993). Nitrogen and foliar fungicide effects on winter wheats. J. Prod. Agric., 6, 53-57. http://dx.doi.org/10.2134/jpa1993.0053

Köhle, H., Grossmann, K., Jabs, T., Gerhard, M., Kaiser, W., Glaab, J., ... Herms, S. (2002). Physiological effects of the strobilurin fungicide F 500 on plants. Modern Fungicides and Antifungal Compounds III (pp. 61-74).

Nash, P. R., Motavalli, P. P., \& Nelson, K. A. (2012). Nitrous oxide emissions from claypan soils due to nitrogen fertilizer source and tillage/fertilizer placement practices. Soil Sci. Soc. Am. J., 76, 983-993. http://dx.doi.org/10.2136/sssaj2011.0296

Munkvold, G. P., Martinson, C. A., Shriver, J. M., \& Dixon, P. M. (2001). Probabilities for profitable fungicide use against gray leaf spot in hybrid maize. Phytopathology, 91, 477-484. http://dx.doi.org/10.1094/PHYTO.2001.91.5.477

Nash, P. R., Nelson, K. A., Motavalli, P. P., \& Anderson, S. H. (2015). Corn yield response to managed drainage and polymer-coated urea. Agron. J., 207, 1-7. http://dx.doi.org/10.2134/agronj14.0273

NASS. (2009). USDA National Agricultural Statistics Service. Online. Retrieved November 11, 2009, from http://www.nass.usda.gov/QuickStats/Create_Federal_Indv.jsp

Nelson, K. A., \& Meinhardt, C. G. (2011). Foliar boron and pyraclostrobin effects on corn yield. Agron. J., 103, 1352-1358. http://dx.doi.org/10.2134/agronj2011.0090

Nelson, K. A., Motavalli, P. P., \& Dudenhoeffer, C. J. (2014). Cropping system affects polymer-coated urea release and corn yield response. J. Agron. and Crop Sci., 200, 54-65. http://dx.doi.org/10.1111/jac.1240

Nelson, K. A., Scharf, P. C., Stevens, W. G., \& Burdick, B. A. (2011). Rescue nitrogen applications for corn. Soil Sci. Soc. Am. J., 75, 143-151. http://dx.doi.org/10.2136/sssaj2009.0456

Novoa, R. S. A., \& Villagrán, N. A. (2002). Evaluation of a chlorophyll meter on the assessment of foliar nitrogen in corn. Agricultura Técnica, 62, 166-171.

Paulsen, M. R., Pordesimo, L. O., Singh, M., Mbuvi, S. W., \& Ye, B. (2003). Maize starch yield calibrations with $\begin{array}{llll}\text { near infrared } \quad \text { reflectance. Biosystems } & \text { Engineering, 85, }\end{array}$ http://dx.doi.org/10.1016/S1537-5110(03)00082-5

Paulsen, M. R., \& Singh, M. (2004). Calibration of a near-infrared transmission grain analyzer for extractable starch in maize. Biosystems Engineering, 89, 79-83. http://dx.doi.org/10.1016/j.biosystemseng.2004.05.009

Pataky, J. K., \& Eastburn, D. M. (1993). Comparing partial resistance to Puccinia sorghi and application of fungicides for controlling common rust on sweet corn. Phytopathology, 83, 1046-1051. http://dx.doi.org/10.1094/Phyto-83-1046 
Perkins, J. M., \& Pedersen, W. L. (1987). Disease development and yield losses associated with northern leaf blight on corn. Plant Dis., 71, 940-943. http://dx.doi.org/10.1094/PD-71-0940

Ritchie, S. W., Hanway, J. J., \& Benson, G. O. (1993). How a corn plant develops. Iowa State Coop. Ext. Serv. Spec. Rep. 48. Ames, IA.

Rodriguez-Ardon, R., Scott, G. E., \& King, S. B. (1980). Maize yield losses caused by southern corn rust. Crop Sci., 20, 812-814. http://dx.doi.org/10.2135/cropsci1980.0011183X002000060035x

Scharf, P. C., Brouder, S. M., \& Hoeft, R. G. (2006). Chlorophyll meter readings can predict nitrogen need and yield response of corn in the North-central USA. Agron. J., 98, 655-665. http://dx.doi.org/10.2134/agronj2005.0070

Scharf, P. C., Shannon, D. K., Palm, H. L., Sudduth, K. A., Drummond, S. T., Kitchen, N. R., ... Oliveira, L. F. (2011). Sensor-based nitrogen applications out-performed producer-chosen rates for corn in on-farm demonstrations. Agron. J., 103, 1683-1691. http://dx.doi.org/10.2134/agronj2011.0164

Scharf, P. C., Wiebold, W. J., \& Lory, J. A. (2002). Corn yield response to nitrogen fertilizer timing and deficiency level. Agron. J., 94, 435-441. http://dx.doi.org/10.2134/agronj2002.4350

Shah, D. A., \& Dillard, H. R. (2010). Managing foliar diseases of processing sweet corn in New York with strobilurin fungicides. Plant Dis., 94, 213-220. http://dx.doi.org/10.1094/PDIS-94-2-0213

Shetley, J., Nelson, K. A., Stevens, W. G., Dunn, D., Burdick, B., Motavalli, P. P., ... Dudenhoeffer, C. J. (2015). Corn yield response to pyraclostrobin with foliar fertilizers. J. Agric. Sci., 7, 18-34. http://dx.doi.org/10.5539/jas.v7n7p18

Singh, M., Paulsen, M. R., Tian, L., \& Yao, H. (2005). Site-specific study of corn protein, oil, and extractable starch variability using NIT spectroscopy. Applied Engineering in Agriculture, 21, 229-251. http://dx.doi.org/10.13031/2013.18138

Sripada, R. P., Heiniger, R. W., White, J. G., \& Weisz, R. (2005). Aerial color infrared photography for determining late-season nitrogen requirements in corn. Agron. J., 97, 1443-1451. http://dx.doi.org/10.2134/agronj2004.0314

Tomar, J. S., MacKenzie, A. F., Mehuys, G. R., \& Alli, I. (1988). Corn growth with foliar nitrogen, soil-applied $\begin{array}{llllll}\text { nitrogen, and legume intercrops Agron. } & \text { J., } & 802 & \text { 802-807. }\end{array}$ http://dx.doi.org/10.2134/agronj1988.00021962008000050022x

USDA-NASS. (2015). National Statistics for Corn. Retrieved January 26, 2015, from http://www.nass.usda.gov/Statistics_by_Subject/result.php?F5FD8DD6-C8EF-33C6-AB1F-AD389D9CE6 E9\&sector $=$ CROPS\&group $=$ FIELD $\% 20$ CROPS\& comm $=$ CORN

Ward, J. M. J., Laing, M. D., \& Rijkenberg, F. H. J. (1997). Frequency and timing of fungicide applications for the control of gray leaf spot in maize. Plant Dis., 81, 41-48. http://dx.doi.org/10.1094/PDIS.1997.81.1.41

Ward, J. M. J., Stromberg, E. L., Nowell, D. C., \& Nutter, Jr., F. W. (1999). Gray leaf spot. A disease of global importance in maize production. Plant Dis., 83, 884-895. http://dx.doi.org/10.1094/PDIS.1999.83.10.884

Wegulo, S. N., Martinson, C. A., Rivera-C., J. M., \& Nutter, Jr. F. W. (1997). Model for economic analysis of fungicide usage in hybrid seed production. Plant Dis., 81, 415-422. http://dx.doi.org/10.1094/PDIS.1997.81.4.415

Woloshuk, C., \& Wise, K. (2008). Diplodia ear rot (p. 3). Purdue Univ.

Zhang, J., Blackmer, A. M., Ellsworth, J. W., Kyveryga, P. M., \& Blackmer, T. M. (2008). Luxury production of leaf chlorophyll and mid-season recovery from nitrogen deficiencies in corn. Agron. J., 100, 658-664. http://dx.doi.org/10.2134/agronj2006.0154

Zhang, J., Koehler, K. J., Ellsworth, J. W., \& Blackmer, A. M. (2008). Sensitivity of chlorophyll meters for diagnosing nitrogen deficiencies of corn in production agriculture. Agron. J., 100, 543-550. http://dx.doi.org/10.2134/agronj2006.0153

Ziadi, N., Brassard, M., Bélanger, G., Claessens, A., Tremblay, N., Cambouris, A. N., ... Parent, L. (2008). Chlorophyll measurements and nitrogen nutrition index for the evaluation of corn nitrogen status. Agron. J., 100, 1264-1273. http://dx.doi.org/10.2134/agronj2008.0016 


\section{Copyrights}

Copyright for this article is retained by the author(s), with first publication rights granted to the journal.

This is an open-access article distributed under the terms and conditions of the Creative Commons Attribution license (http://creativecommons.org/licenses/by/3.0/). 